\title{
IAMJ
}

INTERNATIONAL

AYURVEDIC

MEDICAL JOURNAL

\section{A CASE STUDY ON ESSENTIAL HYPERTENSION MANAGING THROUGH AYURVEDA W.S.R. RAKTAGATA VYAN VAISHAMYA}

\author{
Ruhi Zahir', Iqbal Khan ${ }^{2}$ \\ ${ }^{1}$ Assistant Professor, P.G. Dept. Of Kaya Chikitsa, M.M.M. Govt. Ayurveda College, Udaipur, Rajasthan, \\ India \\ ${ }^{2}$ P.G. Scholar, P.G. Dept. Of Kriya Sharir, M.M.M. Govt. Ayurveda College, Udaipur, Rajasthan, India
}

Corresponding Author: dr.ruhizahir@gmail.com

\section{https://doi.org/10.46607/iamj16p5042021}

(Published online: May 2021)

Open Access

(C) International Ayurvedic Medical Journal, India 2021

Article Received: 29/05/2021 - Peer Reviewed: 30/05/2021 - Accepted for Publication: 31/05/2021

Check for updates

\section{ABSTRACT}

Essential hypertension is high blood pressure that doesn't have any known etiopathology. Most of sufferers $(85 \%)$ are asymptomatic and as per available reports, in more than $95 \%$ cases of hypertension under lying cause is not found. It is estimated that 600 million people are affected worldwide. Hypertension is a major risk factor for the development of cardiovascular diseases (CVD). Its impact is greatest on stroke, MI and end stage is renal failure as it's known as a Silent Killer. Hence there is no direct reference of hypertension in Ayurvedic classics by name as well as by its path physiological views. Many works have been carried out on hypertension to evaluate the perfect diagnosis and mode of treatment on the basis of Different nomenclatures also have been adopted by Ayurveda experts like Raktagata Vata, Raktagata Vyana Vaisamya, Uccha Rakta Chapa, Raktavrita Vata, Siragata Vata etc.

Keywords: Essential hypertension, Raktagata Vyana Vaisamya, Uccha Rakta Chapa, Cardiovascular diseases, Silent Killer.

\section{INTRODUCTION}

Essential hypertension is high blood pressure that doesn't have any known etiopathology. As most of the patients suffering from a normally elevated blood pressure are asymptomatic, diagnosis is either missed or delayed. Essential hypertension is an instrumental disease which is the recent diagnostic invention of modern science. In essential hypertension different views have been adopted, but 
no one has denied the fact that in Raktagata Vyana Vaisamya because the main pathogenesis occurs in Rasa and Rakta dhatu in blood vessels with the alteration in all the three Doshas. Common abnormalities are elevated lipid profile level, uremia, proteinuria, elevated FBS and PPBS level, abnormal ECG etc.

\section{Case Report}

A 54-Year-old male patient came to Kayachikitsa OPD of Govt. Ayurveda Hosital, Motichohta, Udaipur associated with M.M.M. Govt. Ayurveda College, Udaipur, with the chief complain of dizziness since 5 days with no other symptoms. Hypertension was diagnosed 6 years ago when blood pressure measured on the routine check-up around $174 / 100 \mathrm{~mm} \mathrm{Hg}$ on three occasions and a pulse of $84 \mathrm{bpm}$. Patient was initially treated with Amlodipine $5 \mathrm{mg}$ daily for 3 years than shifted to the combination of Losartan $50 \mathrm{mg}$ and Hydrochlorothiazide $12.5 \mathrm{mg}$. Yet his BP control had fluctuated. His family history is positive for Hypertension. Physical assessment is unremarkable except for the presence of moderate obesity $\left(5^{\prime} 7\right.$ " \& $92 \mathrm{~kg}$.) and minimal varicose veins. Other laboratory investigations and vital signs were abnormal as he had hypercholestrolemia and high serum creatinine level from past 2 year.

\section{Vitals before Treatment:}

Blood pressure- 174/100 mmHg

Pulse Rate- 84/ minute

Temperature- 98.9 F, Afebrile

Respiratory Rate- 22/ minute

Others- Oedema, pallor, icterus, lymphadenopathy absent

General condition - Normal

Systemic Examination:

Rest of the systemic examination did not reveal any significant abnormality.

\section{Dashvidh Pariksha:}
1. Prakriti-Pitta-Kaphaj
2. Vikriti-Vata-pitta
3. Saar-Meda
4. Samhanan-Madhyama
5. Satmaya-Vyamishra
6. Satva-Pravara
7. Pramaan-Madhyama
8. Aahar Sakti-Madhyama
9. Vyayaam Shakti-Pravara
10. Vaya-Prodhavastha

\section{H/O Past Illness:}

\section{NAD}

Table 1: Drug Administration:

\begin{tabular}{|l|l|l|l|l|l|l|}
\hline S.No. & Drug Name & Dose & Anupaan/Sahpaan & Days & Time & Specific \\
\hline $\mathbf{1}$ & Sarpagandha Ghan Vati & $500 \mathrm{mg}$ & Water & 60 & BD & AF \\
\hline $\mathbf{2}$ & Arjun Twak Choorna & $10 \mathrm{gm}$ & Milk (As Kheer Paak) & 60 & OD & In Breakfast \\
\hline $\mathbf{3}$ & Trinpanchmoola Kwath & $15 \mathrm{ml}$ & Lukewarm Water & 60 & BD & BF \\
\hline $\mathbf{4}$ & Punarnavasava & $15 \mathrm{ml}$ & Lukewarm Water & 60 & BD & BF \\
\hline $\mathbf{5}$ & Gokshuradi Guggulu & $500 \mathrm{mg}$ & Water & 60 & BD & AF \\
\hline $\mathbf{6}$ & Chandraprabha Vati & $250 \mathrm{mg}$ & Honey & 60 & BD & AF \\
\hline
\end{tabular}

We gave mild purgation with Erand oil $50 \mathrm{ml}$ with hot milk on $1^{\text {st }}$ day. Patient had been followed up every 10 days for 2 months.

Table 2: Laboratory Investigation

\begin{tabular}{|l|l|l|l|}
\hline S.No. & Biochemical Parameters & Before Treatment & After Treatment \\
\hline $\mathbf{1}$ & S. Cholesterol & $226 \mathrm{mg} / \mathrm{dl}$ & $178 \mathrm{mg} / \mathrm{dl}$ \\
\hline $\mathbf{2}$ & Triglyceride & $158 \mathrm{mg} / \mathrm{dl}$ & $144 \mathrm{mg} / \mathrm{dl}$ \\
\hline $\mathbf{3}$ & HDL & $38 \mathrm{mg} / \mathrm{dl}$ & $42 \mathrm{mg} / \mathrm{dl}$ \\
\hline $\mathbf{4}$ & LDL & $142 \mathrm{mg} / \mathrm{dl}$ & $124 \mathrm{mg} / \mathrm{dl}$ \\
\hline $\mathbf{5}$ & VLDL & $36 \mathrm{mg} / \mathrm{dl}$ & $28 \mathrm{mg} / \mathrm{dl}$ \\
\hline $\mathbf{6}$ & Blood Urea & $38.4 \mathrm{mg} / \mathrm{dl}$ & $26.6 \mathrm{mg} / \mathrm{dl}$ \\
\hline $\mathbf{7}$ & S. Creatinine & $2.1 \mathrm{mg} / \mathrm{dl}$ & $1.2 \mathrm{mg} / \mathrm{dl}$ \\
\hline $\mathbf{8}$ & Uric Acid & $7.4 \mathrm{mg} / \mathrm{dl}$ & $5.8 \mathrm{mg} / \mathrm{dl}$ \\
\hline
\end{tabular}


Table 3: Vitals During treatment

\begin{tabular}{|l|l|l|l|l|l|l|l|l|}
$\begin{array}{l}\text { S. } \\
\text { No. }\end{array}$ & $\begin{array}{l}\mathbf{0} \\
\text { dariables }\end{array}$ & $\begin{array}{l}\mathbf{1 0} \\
\text { day }\end{array}$ & $\begin{array}{l}\mathbf{2 0} \\
\text { day }\end{array}$ & $\begin{array}{l}\mathbf{3 0} \\
\text { day }\end{array}$ & $\begin{array}{l}\mathbf{4 0} \\
\text { day }\end{array}$ & $\begin{array}{l}\mathbf{5 0} \\
\text { day }\end{array}$ & $\begin{array}{l}\mathbf{6 0} \\
\text { day }\end{array}$ \\
\hline $\mathbf{1}$ & $\begin{array}{l}\text { Blood pressure (SystolisBP /Diastolic BP in } \\
\text { mmHg) }\end{array}$ & $174 / 100$ & $166 / 94$ & $154 / 92$ & $146 / 88$ & $134 / 84$ & $128 / 82$ & $118 / 78$ \\
\hline $\mathbf{2}$ & Pulse rate (bpm) & 84 & 82 & 78 & 80 & 74 & 72 & 72 \\
\hline $\mathbf{3}$ & Pulse Pressure (in mmHg) & 74 & 70 & 62 & 58 & 50 & 46 & 40 \\
\hline $\mathbf{4}$ & Respiratory Rate (per Minute) & 22 & 20 & 22 & 18 & 18 & 20 & 18 \\
\hline
\end{tabular}

\section{DISCUSSION}

The disease Essential Hypertension has no such clear-cut reference in Ayurvedic texts. But from compilation of scattered references it is concluded that, EHT is a Vata pradhana Tridoshaja Vyadhi. These vitiated Doshas leads to vitiation of Rasavaha, Raktavaha and Manovaha srotas. Rasa and Rakta are the chief culprits which associated with vitiation of psychological factors i.e. Raja and Tama. The main pathology occurs in Rasa-Rakta Dhatu. As the Adhisthana of the disease is Hridaya. The line of Ayurvedic management of Raktagata Vyana Vaisamya is application of Sarpagandha Ghan Vati, Arjun Twak Choorna(as Kher Paka), Trinpanchmoola Kwath, Punarnavasava, Gokshuradi Giggulu, Chandraparbha Vati with the modification in normal diet to DASH Diet (Dietary Approach to Stop Hypertension) and motivate to do Yogaasan in daily schedule like Surya Namaskar, Sawasan, Pranayam, Anulom-Vilom and Meditation. Which are Shada-Indriya Prasadana, Preenana, Vata Pitta Shamaka, Hridya, Mutral, Virechak, Daha-Murccha Prashamana, Nidra janak etc.

Raktagata Vyana Vaishamya is Vata Pradhana Tridoshaja Vyadhi so being Vata Pitta Shamaka it helped in Samprapti Vighatana. Sarpagandha Ghan Vati has Tikta Rasa, Ruksha guna, Ushna Veerya and Katu Vipaka all helps in Samprapti Vighatana of Raktagata Vyana Vaishmya. By Nidrajanaka Prabhava it helps in reducing the mental stress, Giddiness, Cardiac Palpitations etc. Sarpagandha has itself work as a bronchodilator that gives immediate hypotensive activity. The Indian political leader Mahatma Gandhi was known to employ Rauwolfia, reportedly using the root to make a tea that he consumed in the evening to help relax after a busy day.

Most of the studies, both experimental and clinical, have suggested that the crude drug possesses antiischemic, antioxidant, hypolipidemic, and antiatherogenic activities. Its useful phytoconstituents are: Triterpenoids, $\beta$-sitosterol, flavonoids, and glycosides. Triterpenoids and flavonoids are considered to be responsible for its beneficial antioxidant cardiovascular properties. The drug has shown promising effect on ischemic cardiomyopathy. So far, no serious side effects have been reported with Arjuna therapy. However, its long-term safety still remains to be elucidated. Though it has been found quite useful in angina pectoris, mild hypertension, and dyslipidemia, its exact role in primary/secondary coronary prevention is yet to be explored. Animal experiments have demonstrated that Arjuna bark powder/extract reduces the total cholesterol (TC) and triglyceride (TG) levels.

Further, it along with Gokshuradi Guggulu, Trinpanchamoola Kwatha, Punarnavasava and Chandraprabha Vati not only reduced the fluid overload due to renal impairment by diuretic action but also strengthen the renal and cardiac systems.

Hypoxanthine and boeravinones which are active antihypertensive agents of Punarnava acts as $\mathrm{Ca}+2$ channel antagonist. It also acts as diuretic by increasing renal blood flow by relaxing the smooth muscles of the arterial wall.

Gokshura had a significant action in reduction of clinical symptoms, systolic and diastolic blood pressure without any side effects on the patients of mild to moderate essential hypertension. Therefore, this plant diuretic can be safely recommended for a longer period to the patients of mild to moderate hypertension.

These results significantly show that Chandraprabha Vati (CV) can function as a diuretic as claimed in Ayurvedic medicine and acts via multiple mechanisms (Osmotic, thiazide, potassium sparing, loop diuretic and promoting glomerular filtration rate). It is concluded that, $\mathrm{CV}$ can as function as potent, safe diuretic as claimed in 
Ayurvedic medicine. Further, it is used in several clinical conditions such as obesity, diabetes mellitus, skin infections, gastrointestinal disorders, impotency, pre-mature aging and urinary tract diseases. CV induced a marked and significant increase by glomerular filtration rate as creatinine clearance.

\section{CONCLUSION}

Vata is the main causative factor for Hypertension as per Ayurved. It may be due to obstruction of Pitta or Kapha Avarana. Sarpagandha Ghan Vati, Arjun Twak Kheer Paak, Gokshuradi Guggulu, Trinpanchamoola Kwatha, Punarnavasava and Chandraprabha vati are the useful medicine in Hypertension. As many interventions are used in this case, so it is difficult to understand by which intervention patient got relief but all are work as a black box intervention as cardio protective, vasodilator, antioxidant, diuretic, $\mathrm{Ca}+2$ channel antagonist Purgative, Reno protective and mental stress reliever. Patient got significant relief. Large scale clinical trial should be done to establish it as general treatment for Hypertension.

\section{REFERENCES}

1. $\mathrm{ABC}$ of Hypertension, edited by Eoin O' Brien; D. Gareth; Beevers; Hpward. J. Marshall, BMJ Publication, 1995, 3rd edition, p. 58.

2. Anonymus, Rasatantrasaar \& Siddhaprayogasangraha Part I, Krishnagopal Ayurved Bhavan, Kaleda Krishnagopala, 23rd edition, 2014, p.250.

3. API - Database of Medicinal Plants- Database on Medicinal Plants used in Ayurved Vol. I-VI, Reprint edition, 2012, CCRAS, Dept. of ISM \& H, Govt. of India.

4. API Textbook of Medicine, Vol.1, Hypertension, Section 12, Chapter 20, 9th Edition, p.689.

5. Charaka, Charaka Samhita, Acharya Y.T. (editor), Chaukhamba Surbharati Prakashana, Varanasi, Reprint 2008, Sutrasthana 20/11, p. 113.

6. Charaka, Charaka Samhita, Acharya Y.T. (editor), Chaukhamba Surbharati Prakashana, Varanasi, Reprint 2008, Sutrasthana p. 269.

7. Charaka, Charaka Samhita, Acharya Y.T. (editor), Chaukhamba Surbharati Prakashana, Varanasi, Reprint 2008, p. 274.

8. Devidson's Principles \& Practice of Medicine, Cardiovascular diseases, Chapter 18,21st edition, p. 580.

9. Fuci AS, Braunwald E, Kasper DL. Altercations in renal and urinary tract function: Harrisons's principle of internal medicine, 17th ed, McGrawltill medical: NY,2008; pp. 268-96.

10. Gayathri J, Anuradha R. International journal of pharmacology \& biological sciences 4.4 (dec 2010); 115-120.

11. Harrison principal of medicines, Harrison Principles of Internal Medicine-Editors-Brian L. Casper \& others19thedition, Vol.-I, Publishers - McGraw hill Education, Chapter 241, 9th edition, p.1549.

12. Iswariah V, Subramaniam R, Guruswami M N, Pharmacological study and clinical observations on rauwolfia alkaloid (R.S. 51) a hypotensive agent. Indian J. 'M. Sc. 8: 257, 1954.

13. Khanna AK, Chander C, Kapoor NK. Terminalia arjuna: An Ayurvedic cardiotonic regulates lipid metabolism in hyperlipidemic rats. Phytother Res. 1996; 10:663-5. [Google Scholar]

14. Murthy AR, Dubey SD, Tripathi K. Antihypertensive effect of Gokshura (Tribulus terrestris Linn.) A clinical study. Anc Sci Life. 2000; 19(34):139-145.

15. Nayak S, Nayak S, Dash DP, et al. A Clinical Study on the Effect of Boerhaavia Diffusa (Punarnava) in Essential Hypertension. Ayushdhara. 2015; 2(6):390-396.

16. Sastri P. Saranghadhara Samhita: Pandit Sharanghadharacharya with the Commentary of Kashinatha Shastrina (Sanskrit). Sri Rama Presa yantralaye mudrita, India, pp.131-32.

17. Srivastava Shailja, Sharangdhar Samhita, Chaukhambha sanskrit santhan, Varanasi chap 7: 205.

18. Susruta, Nibandha sangraha commentary by Dalhana, edited by Vaidya Jadavaji Trikamaji Acharya, 7th edition, Chaukhamba publications 2002, $p 741$

19. Ram A, Lauria P, Gupta R, Kumar P, Sharma VN. Hypocholesterolaemic effects of Terminaliaarjuna tree bark. J Ethnopharmacol. 1997; 55:1659. [PubMed] [Google Scholar]

20. Yadav ji trikram ji, ras tantra sara \& sidha yoga sangraha, part I, Krishna gopal ayurveda bhawan, Kaleda, H.P. India, bhasma prakrana, p. 93.

\section{Source of Support: Nil Conflict of Interest: None Declared}

How to cite this URL: Ruhi Zahir \& Iqbal Khan: A Case Study On Essential Hypertension Managing Through Ayurveda W.S.R. Raktagata Vyan Vaishamya. International Ayurvedic Medical Journal \{online\} 2021 \{cited May, 2021\} Available from: http://www.iamj.in/posts/images/upload/2965 2968.pdf 